Vol. 39(4) 2002

\title{
A Choice Among Values: \\ Theoretical and Historical Perspectives ON THE DEFENCE OF NECESSITY
}

\author{
BENJAMIN L. BERGER*
}

The author explores various theoretical approaches to the defence of necessity, rejecting both excusatory conceptions of the defence and those based on the notion of moral involuntariness. Rather, the author argues that necessity is properly understood as a justificatory defence based on a lack of moral blameworthiness. After extensively surveying the history of the defence in Canadian law, the author critiques the way in which the Supreme Court of Canada has restricted the defence. He contrasts the current Canadian approach with the treatment of the defence in other jurisdictions and concludes that Canadian law would be served best by a robust defence of necessity. which would acknowledge that, in some circumstances, pursuit of a value of greater worth than the value of adherence to the law can be justified.
L'auteur examine diverses démarches théoriques da la défense de la nécessité, rejetant les conceptions d'excuse de la défense et celles qui sont fondées sur la notion de caractère involontaire du point de vue moral. L'auteur argumente plutöt le fait que la nécessité est bien acceptée dans le cas de défense justifiable fondée sur un manque de répréhension morale. Après un examen approfondi de l'histoire de la défense dans le droit canadien, l'auteur fail la critique de la manière dans laquelle la Cour suprème du Canada a limité la défense. Il compare la démarche canadienne actuelle au traitement de la défense dans d'autres juridictions, et conclut que la loi canadienne pourrait profiter d'une solide défense de la nécessité, reconnaissant ainsi que dans certains cas, on peut justifier la poursuite de la valeur d'un plus grand mérite plutöt que la valeur du respect de la loi.

Table of Contents

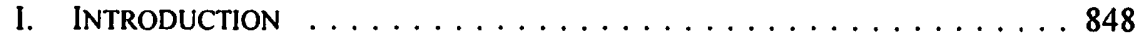

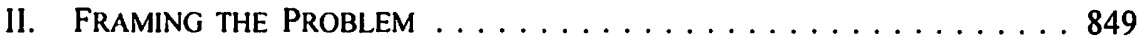

III. THE HISTORY OF NECESSITY . . . . . . . . . . . . . . . . 852

IV. THE MODERN CONTEXT - CANADA AND THE WORLD $\ldots \ldots \ldots 856$

V. CONCLUSION ....................... 863

\section{INTRODUCTION}

The defence of necessity has long been a source of heated debate in Anglo-Canadian criminal jurisprudence. Theorists have spun hypothetical situations that test the limits of the law of necessity, and philosophers have analyzed the ethical dimension of the problems posed by the defence. Indeed, the defence of necessity can be viewed as a conceptual touchstone for broad questions about the purposes of criminal law and the nature of criminal responsibility. Necessity draws out understandings of blameworthiness and tests our frameworks of values. Despite this historical attention and theoretical consequence, necessity does not cut a significant figure in contemporary Canadian criminal law. It is neither a defence recognized explicitly in the Criminal Code nor is it one that frequently finds its way before our courts. When it has come under judicial scrutiny, our courts have closely circumscribed and even constricted the defence.

Student, Faculty of Law, University of Victoria, British Columbia; Law Clerk to McLachlin C.J.C. of the Supreme Court of Canada for 2002/2003. The author wishes to thank Professor Gerry Ferguson for his guidance and support in the preparation of this article. 
Canada's nearly moribund defence of necessity leaves a gap in our criminal jurisprudence. It creates an aspect of the criminal law that is neither logically consistent nor morally sufficient. By first locating the defence in a philosophical landscape, one can appreciate the role that a vital defence of necessity ought to assume. From this point it is instructive to trace the history of our inheritance of the law from its English sources with a view to understanding the defence in its modern context. Finally, drawing from the wisdom of this history and the legal frameworks found in other jurisdictions, one can construct a robust and morally adequate defence of necessity that could serve an increasingly germane role in our criminal law.

\section{Framing the Problen}

Two of the core tenets of Canadian criminal law are that only the morally blameworthy ought to be punished and only punished in accordance with the degree of their blameworthiness. The entire criminal justice process is fundamentally focused upon discerning who ought to be punished and to what degree. The procedural guarantees and substantive fairness requirements provided at common law, and now assured by the Charter, seek to ensure that only those "deserving" of punishment receive criminal sanction. One jurisprudential tool consummately concerned with the attribution and avoidance of blame is the law of defences.

Simply, defences provide means by which an accused individual can assert that he or she is not blameworthy. Of course, this assertion can be made in many ways. Under the defence of intoxication the accused claims that he did not possess the requisite mens rea to be convicted of the specific offence charged. An accused who argues self-defence concedes that he acted intentionally, but asserts that he had every right to take the actions that he did. The defence of provocation functions as a concession to human frailty in that, based on the emotional state of the accused, it reduces murder to manslaughter and thereby mitigates the punishment for an unlawful act for which the requisite mens rea and actus reus exist. In each of these examples, the defence is making a somewhat different claim about the lack diminished nature of the accused's blameworthiness.

So upon what claim does the defence of necessity rest? In his Commentaries, William Blackstone suggested one possible understanding of claims of necessity:

These are a constraint upon the will, whereby a man is urged to do that which his judgment disapproves, and which, it is to be presumed, his will (if left to itself) would reject. As punishments are, therefore. only inflicted for abuse of that free-will which God has given to man, it is highly just and equitable that a man should be excused for those acts which are done through unavoidable force and compulsion.'

Blackstone contends that necessity amounts to a claim that the accused was acting in a state of moral involuntariness. Factors outside of the accused's control leave him little practical choice but to act in a particular way, perhaps a way in which he would not normally have chosen to act if these factors were not present. Such a defect in the will 
would render punishment for the act unjust. A similar explanation is provided by David Jones, who argues that "[o]ne who acts or fails to act out of necessity does not do so through his own free choice even though he may consciously decide to do what he does." 2

The problem with this contention is that, short of utter involuntariness akin to automatism, the will is always operating. Can it properly be said that the person who steals, motivated by the extreme hunger of her family, is operating without will? Even more so, if this "thief" pauses to recognize that a law exists that prohibits her from stealing but, on balance, decides that it is more important to take the food, is it accurate to say that she is in a state of moral involuntariness? Clearly, circumstance suggests a particular course of action, but it is not accurate to adopt the position that this thief had no choice - that the act was involuntary. A moral choice is still made, and, therefore, the act cannot be said to be "unavoidable." But what Blackstone does demonstrate is that, for various reasons, it would be wrong to punish a person whose will was so strongly influenced by hardship or emergency. The principle that seems to present is that the defence of necessity embraces those situations where, by the operation of circumstance, the accused cannot be said to be morally blameworthy for his actions.

This proposition is consistent with other areas of the criminal law. Indeed, the concept of mens rea operates to ensure that only the morally blameworthy are punished. To the degree that the content of mens rea varies from crime to crime, this variance reflects our assessment of the level of blameworthiness required in order to punish an individual for commission of the offence. As such, where a great deal of stigma and a severe punishment attendant upon conviction for a given offence exist, our law requires that the moral blameworthiness be demonstrated through subjective means. At the other end of the spectrum, absolute liability offences ask only that the act be committed and require no subjective blameworthiness. Other defences like duress allow those compelled by other persons' unlawful threats to be excused from punishment for certain offences. Indeed, some have argued that the very existence of the defence of duress argues for a recognition of necessity, because there would be an "evident illogicality involved in excusing one who acts under pressure from wrongful threats of the 'do this or else' ... variety while not excusing one who acts under equally strong pressure from the circumstances."

So if one accepts the principle that underlies Blackstone's understanding of necessity but rejects the proposition that it arises from moral involuntariness, what is an acceptable understanding of the defence? One approach is to conceive of necessity as a defence that operates as an excuse only - a defence that concedes the wrongfulness of the act but argues that no punishment ought to be imposed. This approach is taken by Immanuel Kant when he considers the case of a drowning man banishing another from a plank of wood capable of supporting only one: "An act of violent self-preservation, then, ought not to be considered as altogether beyond condemnation (inculpabile); it is only to be adjudged 
as exempt from punishment (impunibile). ${ }^{\prime 4}$ George Fletcher understands the great advance in this reasoning as residing in the recognition that the sole fact that an act is unlawful is not conclusive of the issue of liability. ${ }^{5}$ This approach of confining necessity to an excuse sidesteps the problem of requiring a wholly bound will because even a lesser "compulsion" can work to mitigate punishment.

However, limiting necessity to an excuse poses troubling illogicalities. What of a person who, in the woods and near death from starvation, steals a can of food from an abandoned shack? If one adopts the necessity-only-as-excuse rationale, then the only possible conclusion is that this act was unlawful. In effect, the person acted wrongfully by taking the food. The fact that no punishment will be imposed does not detract from the nominal condemnation of an act that does not seem morally condemnable. This conceptual difficulty illustrates the proposition that "[q]uestions of justification are part of the theory of crime; excuses are part of the theory of punishment." To the extent that moral blameworthiness is a sine qua non of criminal responsibility, a proper theory of crime should not allow this problematic outcome. The morally consistent result would be to indicate that the accused had made the correct choice and, therefore, had acted lawfully.

So it is the notion of choice that lies at the heart of the defence of necessity. Glanville Williams suggested as much with the following declaration:

By necessity is meant the assertion that conduct promotes some value higher than the value of literal compliance with the law. ${ }^{\text {? }}$

The defence of necessity arises where a choice is made to pursue a value of greater worth than the value of adherence to the law. As such, a successful defence of necessity condones the choice to break the law in the given circumstances. In this understanding, all claims to necessity can be viewed as instances of a choice between the lesser of two evils. The individual in onerous circumstances must decide whether, based on the potential consequences of adhering to the law and the harm averted by following some other value, the act in question should be undertaken. As Galloway points out, this balancing is not merely a utilitarian one of costs and benefits. ${ }^{8}$ Rather, an otherwise unlawful act may be justifiable "a) where purposes rather than results justify; b) where permissible self interest justifies, and c) where redistribution of harm justifies... it is important to emphasize a fourth situation, where one grounds the justification on the premise that the right that is

I. Kant, The Philosophy of Law: An Exposition of the Fundamental Principles of Jurisprudence as the Science of Right, trans. W. Hastic (Edinburgh: T \& T Clark, 1887) at 53.

s.P. Fletcher, Rethinking Criminal Law (Boston: Little, Brown and Company, 1978) at 819. Fletcher is a strong advocate for the conceptual distinguishing of defences that function as justifications and those that operate as excuses. A great deal of the literature addressing necessity focuses upon this division and the problems inherent in patrolling the borders between the two. For the purposes of this article, justifications will be understood as denials of the unlawful nature of an act, whereas excuses concede the unlawfulness but argue that punishment should nevertheless be reduced or withheld.

" A. Ripstein, Equality, Responsibility, and the Law (Cambridge: Cambridge University Press, 1999) at 163.

' G.L. Williams, Criminal Law: The General Part (London: Stevens \& Sons, 1953) at 567.

* D. Galloway, "Necessity as a Justification: A Critique of Perka" (1986) 10 Dal. L.J. 158 at 168. 
infringed is unimportant in comparison with the end that is achieved." ${ }^{\prime 9}$ As such, a choice between killing one for the sake of ten may further the higher ideal of the preservation of life just as the choice to destroy property to prevent a fire from spreading is justified on the basis of the harm it seeks to avoid.

This approach is the most conceptually consistent with the requirement for moral blameworthiness in the criminal law. No resort is made to notions of moral involuntariness, and the illogicalities produced by the excuse conception are avoided. For these reasons, I will argue that this approach is the most appropriate construction of the defence of necessity for Canadian criminal law. Yet before considering the defence in its modern legal context, it is instructive to understand the means by which it entered our criminal law, as well as the attending debates.

\section{THE HiSTORY OF NECESSITY}

In his 1765 Commentaries, Blackstone wrote that he would recognize four kinds of necessity in the criminal law: (1) constraint of a superior, (2) "threats and menaces, which induce a fear of death or other bodily harm," ${ }^{10}$ (3) choices for the lesser of two evils, and (4) want of food or clothing." Blackstone's principled and broad doctrine of necessity would not, however, find universal favour in the English drive for codification in the late nineteenth century.

Edward Livingston sought to abolish all common law crimes and terms not defined in his draft code for Louisiana. He also sought to curtail judicial discretion by forcing application of the letter of the law and constraining flexibility in sentencing. He did not, however, include a necessity provision in his code. The duress provision ${ }^{12}$ contemplates only coercion by persons, and, therefore, his code lacked a means of either justifying or excusing conduct motivated by other types of necessity. This gap goes unmentioned and we do not know what motivated this departure from the principle of criminal liability recognized by Blackstone.

Lord Macauley also failed to provide for a necessity defence in his Draft Indian Penal Code, but his notes on the code explained at length why he had chosen this course. He began by recognizing the redeeming features of such a provision:

[A]s the penal code itself appeals solely to the fears of men, it never can furnish them with motives for braving dangers greater than the dangers with which it threatens them. Its utmost severity will be inefficacious for the purpose of preventing the mass of mankind from yielding to a certain amount of

lbid.

Blackstone, supra note 1 at $28-30$.

Ibid. at 30-31.

E. Livingston, The Complete Works of Edward Livingsion on Criminal Jurisprudence: Consisting of Systems of Penal Law for the State of Lousiana and for the United States of America, vol. 2 (Monclair, New Jersey: Patterson Smith, 1968) at 22. 
temptation. It can. indeed, make those who have yielded to the temptation miserable afterwards. But misery which has no tendency to prevent crime is so much clear evil. ${ }^{13}$

This compelling argument would allow for some latitude in situations where an accused faces "great danger." But Macaulay continued by suggesting that

punishment which is inefficacious to prevent a man from yielding to a certain temptation may often be efficacious to prevent him from exposing himself to that temptation.... We should therefore think it in the highest degree pernicious to enact that no act done under the fear even of instant death should be an offence. It would a fortiori be absurd to enact that no act under the fear of any other evil should be an offence. There are. as we have said, cases in which it would be useless cruelty to punish acts done under the fear of death, or even of evils less than death. But it appears to us impossible precisely to define these cases. We have. therefore. left them to the Government, which. in the exercise of its clemency, will doubtless be guided in a great measure by the advice of the Courts. ${ }^{14}$

Thus Macaulay left the matter of necessity to the discretion of executive clemency. Two concerns that would later influence the development of a Canadian criminal code appear in this statement. First is Macaulay's stated anxiety over the ability to contemplate, with sufficient precision, the cases in which necessity may be a desirable defence. Second, Macaulay was concerned about the effect that a legislated provision allowing for a defence of necessity would have on the deterrence of crime.

Also absent from Wright's draft code prepared for Jamaica, ${ }^{15}$ it was not until 1878 that the defence of necessity would find its way into a proposed code. In 1877 James Fitzjames Stephen's Digest of the Criminal Law indicated that the English common law might excuse a person from criminal liability for an act "done only in order to avoid consequences which could not otherwise be avoided," and for which there was a proportionality between the measures taken and the "evil avoided."16 In 1878 Stephen considered this understanding of the defence of necessity by including the following provision in his draft criminal code:

No act is an offence which is done only in order to avoid consequences which could not otherwise be avoided, and which if they had followed would have inflicted upon the person doing the act, or upon others whom he was bound to protect, inevitable and irreparable evil, and if no more is done than is reasonably necessary for that purpose, and if the evil intended to be inflicted by such act is neither intended nor likely to be disproportionate to the evil intended to be avoided.

No act which causes harm to the person of another is an offence if the person doing it was, without any fault on his part. so situated at the time that he could not avoid doing the act which caused such harm,

13

Lady Trevelyan. ed.. The Works of Lord Macaulay: Complete. vol. 7 (London: Longmans, Green, and Co., 1866) at 454.

it Ibid. at $457-58$.

is U.K., H.L. and H.C., "Drafts of Criminal Code and a Code of Criminal Procedure for the Island of Jamaica, with an Explanatory Memorandum" by R.S. Wright in British Sessional Papers. v. 61 (1877).

16. J.F. Stephen, A Digest of the Criminal Law (Crimes and Punishments), 5th ed. (London: Macmillan and Co., 1894) at 24-25 [hereinafter Digest]. 
without doing some other act which was equally likely to cause harm to some other person (not being himself), and if he did the one act only in order to avoid doing the other. ${ }^{17}$

Despite the restrictions imposed on invoking the defence (e.g., proportionality, least harmful means, no assumption of risk) Stephen's construction of the defence constituted a hard break with the penal reformers that preceded him.

Yet this innovation, a truer reflection of the English law according to Blackstone, was left on the English Commissioners' cutting-room floor. The Royal Commission on Indictable Offences Report, the single most influential document in the development of the 1892 Canadian Criminal Code, included no defence of necessity. Reminiscent of Macaulay's rationale for not including the defence in his code, the Commissioners reasoned that it was

if not absolutely impossible, at least not practicable, to foresee all the various combinations of circumstances which may happen, but which are of so unfrequent occurrence that they have not hitherto been the subject of judicial consideration, although they might constitute a justification or excuse, and to use language at once so precise and clear and comprehensive as to include all cases that ought to be included, and not to include any case that ought to be excluded. ${ }^{18}$

Apparent from this statement is the recognition that necessity may constitute a justification, or at least an excuse. However, also like Macaulay, the Commissioners declared that it would be "better to leave such questions to be dealt with when, if ever, they arise in practice by applying the principles of law to the circumstances of the particular case."

By 1883 Stephen seems to have changed his mind as to the appropriateness of legislating a defence of necessity. In his History of the Criminal Law of England, he echoes the sentiments of the Commissioners and later states that "[ $\mathrm{t}] \mathrm{h}$.re is not, and I think there cannot be, any principle involved in cases of [necessity]." ${ }^{\prime 2}$ Stephen went even further by asserting that " $[t]$ here is no fear that people will be too ready to obey the ordinary law. There is great fear that they would be too ready to avail themselves of exceptions which they might suppose to apply to their circumstances." ${ }^{21}$ Once again, a

U.K., H.C., "Criminal Code (Indictable Offences), 1878" in British Sessional Papers, vol. 2 (1878), s. 23. Stephen goes on to refine his necessity provision to include omissions and to exclude acts done to save a life of an unborn child in favour of the mother. For a discussion regarding Stephen's contribution in preparing the $A c t$, see L. Radzinowicz \& R. Hood, $A$ History of English Criminal Law and its Administration from 1750, vol. 5 (London: Stevens \& Sons, 1986).

U.K., Royal Commission on Indictable Offences, Report of the Royal Commission Appointed to Consider the Law Relating to Indictable Offences: With an Appendix Containing a Draft Code Embodying the Suggestions of the Commissioners (London: G.E. Eyre \& W. Spottiswoode, Her Majesty's Stationery Office, 1879) at 10. lbid. at 44. J.F. Stephen, A General View of the Criminal Law of England, $2 \mathrm{~d}$ ed. (London: Macmillan and Co.. 1890) at 76-77.

21 J.F. Stephen, $A$ History of the Criminal Law of England, vol. 2 (London: Macmillan and Co., 1883) at 110 . 
concern for the deterrent effect of the law combined with anxiety over statutory precision barred necessity from the statutory criminal law.

This latter phase in English jurisprudence would prove critical to the development of Canadian criminal law. Although Burbidge mirrored Stephen's 1877 digest entry, recognizing the defence of necessity almost verbatim, ${ }^{22}$ the Canadian codifiers chose to replicate the Commissioners' approach by not including a necessity provision. This choice went either unnoticed or unmentioned in the House of Commons. ${ }^{23}$ There being no such defence recognized in other Canadian statutes, ${ }^{24}$ the defence of necessity has thus not been included in Canadian legislation on the criminal law. ${ }^{25}$

Most remarkable about this history is that at no point was it suggested that the defence of necessity ought not to have some continuance, though usually in a form of judicial or executive discretion. As reflected in Blackstone's writings as well as Stephen and Burbidge's digests, the defence persisted at common law. The most that some would assert is that it should not be recognized in statute law owing to concerns about deterrence and the limits of statutory precision and foresight. Accepted by the Canadian codifiers, these somewhat specious rationales destined the defence of necessity to a shadowy existence at common law.

This common law existence had, to this point, proven very limited indeed. In his 1890 digest, which sought to summarize the common law, Burbidge indicated that " $[t]$ he extent of this principle is unascertained." ${ }^{26}$ The two illustrations that he offers are idiosyncratic at best. First is an instance in which the Governor of Madras who, after acting in an arbitrary and illegal manner, was deposed and put under arrest by his council. ${ }^{27}$ The judgment of the court indicated that this act was not an offence "if the acts done by the council were the only means by which irreparable mischief to the establishment at Madras could be avoided."28 Second, Burbidge provided the example of two sailors in the sea after a shipwreck. B gets hold of a plank that can only support one man, and A pushes B off, killing him. Burbidge says that this act also is not a crime. ${ }^{29}$

G.W. Burbidge, Digest of the Criminal Law of Canada: founded by permission on Sir James Fitzjames Stephen's Digest of the Criminal Law (Montreal: Carswell \& Co., 1890) at 36-38 [emphasis in original]. To Stephen's provision (Digest, supra note 16) Burbidge added the following reflection: "The extent of this principle is unascertained. It does not extend to the case of shipwrecked sailors who kill a boy, one of their number, in order to eat his body" (at 37).

See J. Crankshaw, The Criminal Code of Canada and the Canada Evidence Act. 1893 (Montreal: Whiteford \& Theoret, 1894). See H.E. Taschereau, The Criminal Statute Law of the Dominion of Canada, Relating to Indictable Offences (Toronto: Carswell \& Co., 1888). Although the Code did expressly recognize the continued existence of non-codified common law defences: Criminal Code, 1892, S.C. 55 \& 56 Vict., c. 29, ss. 7-8. Burbidge, supra note 22 at 37. 
Ultimately, the most influential common law decision in the area of necessity was the famous case of $R$. v. Dudley \& Stephens ${ }^{30}$ in which two sailors survived a shipwreck by killing and eating the flesh of the cabin boy. The Court of Queen's Bench in Exeter refused to recognize the necessity of the situation as a justification or an excuse. Rather, the matter was left to the compassion of the executive branch, compassion that was exercised. In expressing his misgivings about the defence, Lord Coleridge argued that "the absolute divorce of law from morality would be of fatal consequence; and such divorce would follow if the temptation to murder in this case were to be held by law an absolute defence of it." 31 Lord Coleridge put his finger on the key issue with respect to the defence of necessity - the morality of the law. But this observation begs the question: does a restricted or a flexible understanding of necessity better serve the morality of the law? As an answer, English jurisprudence offered only a statutory silence and a highly restrictive common law.

\section{The Modern CONTEXT - Canada AND THE World}

So what has Canadian jurisprudence done in the last century with its inherited law of necessity? I argue above that, owing to the conceptual illogicalities of both the "moral involuntariness" and "necessity-only-as-excuse" explanations, the most satisfying vision of necessity is that, in some circumstances, it is morally correct to pursue a value other than strict adherence to the law. By this view, a necessary act is justifiable. This approach does not preclude necessity from ever amounting to an excuse. Where the balance is unclear or wrongly made, that law may choose to reduce punishment in recognition of the onerous nature of the circumstances. But if an act is truly necessary - where the balancing of values substantially or clearly favours breaking the law - it is most appropriate to justify the accused's conduct.

Canadian criminal jurisprudence has not followed this trajectory. In $R . v . P e r k a^{32}$ the Supreme Court of Canada provided its most thorough articulation of the common law defence of necessity. ${ }^{33}$ Dickson J. (as he was then), speaking for the majority, declares that necessity is an excuse. His concerns with recognizing necessity as a justification hearken back to the concerns of the English codifiers. He argues that a justification through necessity "could well become the last resort of scoundrels." ${ }^{34}$ Why the same could not be said of necessity as an excuse is not clear. What is more, Dickson J. states that to hold that "ostensibly illegal acts can be validated on the basis of their expediency" 35 would require courts to "assess the relative merits of social policies

(1884), L.R. 14 Q.B.D. 273 [hereinafter Dudley \& Stephens].

lbid. at 287.

[1984] 2 S.C.R. 232 [hereinafter Perka]. See also R. v. Hibbert, [1995] 2 S.C.R. 973 where the Supreme Court affirmed its reasoning in Perka.

The common law defence of necessity is preserved in the current Criminal Code, R.S.C. 1985, c. C46, s. 8(3). Section 17, entitled "Compulsion by threats" is the statutory instantiation of the defence of duress.

Perka, supra note 32 at 248.

Ibid. 
underlying criminal prohibitions," ${ }^{" 36}$ a task that he understands as outside the realm of appropriate judicial functions.

When he turns his mind to necessity as an excuse, Dickson J. relies upon two notions criticized above. First, he founds his theory of necessity on the notion of "moral involuntariness." This theory, proposed by Blackstone in 1850, fails to adequately deal with situations in which the accused makes a choice out of necessity that involves engaged moral evaluation. It is not convincing to assert that this accused is acting in any involuntary manner. Secondly, by limiting the defence of necessity to an excuse, Dickson J. requires that the court first condemn any necessary action as unlawful before conceding that blame is not properly assigned. Seemingly, Dickson J. would judge the person who commits a minor property crime to save many lives to have acted wrongly.

In her minority opinion, Wilson J. recognizes these defects and sees that necessity-asjustification "is a door which should be left open by the Court." ${ }^{\text {"W }}$ Wilson wants the court to ask "whether or not the accused acted so as to attract society's moral outrage." ${ }^{\prime 3}$ In the absence of moral condemnation, acts may be said to be rightful rather than wrongful and, therefore, justifiable. Thus Wilson J. rejects the "moral involuntariness" thesis as the central issue in necessity:

Where the defence of necessity is invoked as a justification the issue is simply whether the accused was right in pursuing the course of behaviour giving rise to the charge. ${ }^{39}$

Wilson J., however, unduly limits the kind of duties that can be relied upon to establish that the accused "was right" to exclusively legal duties. This limitation produces the anomalous result, recognized by but apparently not troubling to her, that a person who attempts to rescue a stranger would be "deserving of praise," be justifiable. Apart from this flaw, Wilson J. captures the requirements for a philosophically and morally consistent criminal law. Wilson J.'s minority reasons are conceptually superior to Dickson J.'s.

Fulfilling the fears of Wilson J., the majority judgment has shut the door on necessity as a justification in Canadian criminal law. Additionally, the restrictions that Dickson J. imposed on the defence as an excuse create a situation where an advocate arguing necessity

will be constrained to characterize the accused's conduct as instinctive, to characterize the instinct as normal, to characterize alternative action as demonstrably impossible, and finally to characterize the conduct as a lesser evil than that averted. ${ }^{41}$

$\begin{array}{ll}36 & \text { Ibid. } \\ 3 & \text { Ibid. at } 268 . \\ 3 * & \text { Ibid. at } 270 . \\ 3 & \text { Ibid. at } 279 . \\ \$ & \text { Ibid. at } 276 . \\ \$ 1 & \text { Galloway, supra note } 8 \text { at } 160 .\end{array}$


It is for this reason that the defence of necessity is substantially moribund in Canada.

But the above does not reflect the whole of Canadian thought about the defence of necessity. In 1982 the Law Reform commission succinctly described its view of the defence:

\begin{abstract}
The rationale of necessity, however, is clear. Essentially it involves two factors. One is the avoidance of greater harm or the pursuit of some greater good, the other is the difficulty of compliance with law in emergencies. From these two factors emerge two different but related principles. The first is a utilitarian principle to the effect that, within certain limits, it is justifiable in an emergency to break the letter of the law if breaking the letter of the law will avoid a greater harm than obeying it. The second is a humanitarian principle to the effect that, again within limits, it is excusable in an emergency to break the law if compliance would impose an intolerable burden on the accused. ${ }^{42}$
\end{abstract}

The virtue of this description is that it recognizes that, when an act is truly necessary based on a balancing of interests, the defence should function as a justification. When the balance is not so clear, but an "intolerable burden" imposed by circumstances existing, the defence may be more legitimately used as an excuse. This second functioning is very similar to the "concession to human frailty" model reflected in the defence of provocation. In effect, the Law Reform Commission recognizes that a morally justified act (based on a utilitarian balancing in this formulation) is lawful, while a morally unjustifiable act may, nevertheless, be understandable and, therefore, at least partially excusable.

Necessity is recognized as a justification in a number of foreign jurisdictions. The French Penal Code provides the following:

Article 122-7

A person is not criminally responsible if that person, facing an actual or imminent danger threatening himself, herself, or another, or property, performs an act necessary for the preservation of person or property, unless there is a disproportion between the means employed and the seriousness of the threal. $^{43}$

This elegant provision sets out a broad and simple defence of necessity. Where an act can be said to be necessary to preserve the integrity of a person or of property and is not disproportionate as between the means and the seriousness of the threat, the accused can take advantage of the defence. The difficulty in this provision resides in its failure to define the term "necessary." Under what circumstances can an act be said to be necessary? As well, no provision for excusing an act that falls short of actual necessity exists.

The American Law Institute's Model Penal Code resolves the first defect in the French system:

12 Law Reform Commission of Canada, Working Paper 29: Criminal Law: The General Part Liability and Defences (Ottawa: Law Reform Commission of Canada, 1982) at 93.

" France, The French Penal Code of 1994 (as amended as of January 1, 1999), trans. E.A. Tomlinson (Littleton, Colorado: Fred B. Rothman \& Co., 1999) at 39. 
Section 3.02. Justification Generally: Choice of Evils

(1) Conduct that the actor believes to be necessary to avoid a harm or evil to himself or to another is justifiable, provided that:

(a) the harm or evil sought to be avoided by such conduct is greater than that sought to be prevented by the law defining the offense charged; and

(b) neither the Code nor other law defining the offense provides exceptions or defences dealing with the specific situation involved; and

(c) a legislative purpose to exclude the justification claimed does not otherwise plainly appear.

(2) When the actor was reckless or negligent in bringing about the situation requiring a choice of harms or evils or in appraising the necessity for his conduct, the justification afforded by this Section is unavailable in a prosecution for any offense for which recklessness or negligence, as the case may be, suffices to establish culpability. ${ }^{44}$

This section explicitly recognizes that a choice of evils lies at the core of necessity. The Model Penal Code defines necessity as a situation in which the evil sought to be avoided is greater than the evil that the law proscribes. This Code does not require that the evil avoided be clearly, manifestly, or vastly greater. So long as the preponderance of evil favours committing the act (i.e., greater than 50 percent), the act can be justified as necessary. The American model adds a provision removing the defence from individuals who, charged with crimes for which recklessness or negligence suffices to establish culpability, create the situation that requires the choice of harms. Nevertheless, while justifying truly necessitous acts, this Code does not include a provision that affords an excuse in less clear situations.

The Penal Code of the Federal Republic of Germany seems to offer the best articulation of the defence of necessity:

\section{$\S 34$. Necessity as justification}

Whoever commits an act in order to avert an imminent and otherwise unavoidable danger to the life, limb, liberty, honor, property or other legal interest of himself or of another does not act unlawfully if, taking into consideration all the conflicting interests, in particular the legal ones, and the degree of danger involved, the interest protected by him significantly outweighs the interest which he harms. This rule applies only if the act is an appropriate means to avert the danger

\section{$\$ 35$. Necessity as excuse}

(1) Whoever commits an unlawful act in order to avert an imminent and otherwise unavoidable danger to his own life, limb, or liberty, or to that of a relative or person close to him, acts without guilt. This rule does not apply if under the prevailing circumstances the perpetrator could be expected to have assumed the risk, especially because he was himself the cause of the danger or because he found himself in a special legal relationship. If however, the perpetrator did not have to assume the risk with regard to a special legal relationship, the punishment may be reduced in accordance with the provisions of $\$ 49(1)$. 
(2) If, in committing the act, the perpetrator assumes the existence of circumstances which under subparagraph (1) would excuse his conduct, he shall be punished only if he could have avoided the error. The punishment shall be reduced in accordance with the provisions of $\$ 49(1){ }^{45}$

The justification provision imposes a requirement that the interest protected "significantly outweigh" the interest harmed. This balancing must take place in the context of "all the conflicting interests," and the actions must be appropriate. This provision, though perhaps overembracing in its inclusion of honour as a protected interest, has the virtue of clearly reflecting the philosophical issue at the core of the defence. Where there is a balancing of interests and one significantly outweighs the other, it is lawful to ignore the legal requirement. This position is consistent with the theory of justification; however, this scheme has the further attribute of making a concession to human frailty by partially excusing a person who commits a crime motivated by a desire to protect the life, limb, or liberty of himself or those close to him though the harm avoided does not "significantly outweigh" the evil proscribed. The German Code imposes an additional, and reasonable, limitation that this partial excuse does not apply where the accused causes or could be expected to assume the risk.

An additional legal problem should be addressed in any codification. What is the appropriate result if an accused honestly but mistakenly believes that an act is necessary? The German Code would excuse such an accused unless "he could have avoided the error." Where the act was motivated by an honest but mistaken belief in its necessity, this approach that would allow an accused to take advantage of the defence is consonant with the underlying concern for moral blameworthiness. Indeed, "a person who yields to a strong but imaginary fear may be stupid in imagining it, but he is no more blameworthy than one whose fear is based on reasonable grounds." 46

All of these codes, and particularly the German provisions, provide more theoretically consistent and satisfactory means of recognizing a defence of necessity than presently exist in Canada. They all reflect the requirement of moral blameworthiness without slipping into the rhetoric of "moral involuntariness." All avoid the illogicalities of restricting necessity to the realm of excusatory defences. The most appealing aspect, however, of these codes is the flexibility built into their provisions. Judges are increasingly being asked to make decisions that involve situations where competing values are colliding. Whether this trend is appropriate or not is a debate that yields to the exigencies of reality. The defence of necessity, properly conceived, is a powerful tool in the criminal law for addressing some cases that pose difficult moral questions. Without this tool and the flexibility that it provides, the criminal law compels strict adherence to the letter of the law and, thereby, risks exactly the danger that so concerned Lord Coleridge in Dudley \& Stephens - the severance of law and morality. 
Two case studies are illustrative of this point. The first is $A$ (Children), ${ }^{47}$ a recent and tragic case in which the English Court of Appeal (Civil Division) was called upon to decide whether doctors should separate a set of conjoined twins, thereby condemning one to certain death but likely saving the life of the other. The two children, Jodie and Mary, shared a common aorta. Jodie's heart and lungs were sustaining the life of her sister Mary, but the physiological burden of this condition would, if unaltered, cause the death of both girls. The court had to decide two issues. First, should the operation be performed? Second, and more illuminating to this discussion, if the operation should be performed, could it be performed lawfully? Since the doctors performing the operation recognized that death or serious harm would be virtually certain to occur as a result of the operation, the mental element of murder would be satisfied.

All three judges agreed that the operation should be performed, but each decided the question of lawfulness in a different way. Lord Justice Robert Walker reasoned that "M[ary]'s death would not be the purpose or intention of the surgery," ${ }^{48}$ so the operation could not be said to be unlawful. More interestingly, both Lord Justice Ward and Lord Justice Brooke decided this issue on the basis of a justificatory defence. Although Ward L.J. casts his decision in terms of "quasi self-defence," ${ }^{49}$ he uses the reasoning of necessity to reach this conclusion. Ward asserts that

[t]he respect the law must have for the right to life of each must go in the scales and weigh equally but other factors have to go in the scales as well ... [T] he conclusion has to be that the carrying out of the operation will be justified as the lesser evil and no unlawful act would be committed. ${ }^{50}$

Clearly, Lord Justice Ward is engaging in a balancing of values that leads him to the conclusion that it would be improper to declare that the doctors, in carrying out this operation, would be acting unlawfully.

After reviewing the history of the necessity defence and considering various approaches to the defence, including Canadian jurisprudence, Lord Justice Brooke comes to a similar conclusion, explicitly applying a justificatory defence of necessity. Brooke L.J. confines Dudley \& Stephens to the particular facts that were before that court and distinguishes it from the case at bar. He considers the competing judgments in Perka and clearly favours Wilson J.'s reasons. Ultimately, however, Lord Justice Brooke invokes Stephen's formulation of the defence from his Digest and states simply that

[a]ccording to Sir James Stephen, there are three necessary requirements for the application of the doctrine of necessity:

(i) the act is needed to avoid inevitable and irreparable evil;

(ii) no more should be done than is reasonably necessary for the purpose to be achieved;

[2000] E.W.J. No. 4875 (C.A. (Civ. Div.)), online: QL (EWJ) [hereinafter $A$ (Children)] lbid. at para. 429.

lbid. at para. 213.

lbid. at para. 212. 
(iii)

the evil inflicted must not be disproportionate to the evil avoided. ${ }^{51}$

Having satisfied himself that these three criteria have been met in this case, Brooke LJ. finds that the act would be justified.

It is clear that a similar result would not be possible in Canada. Not only has the Supreme Court of Canada closed the door on necessity as a justification, but the constraints placed upon necessity as an excuse would seem to prohibit Canadian doctors in similar circumstances from taking advantage of this defence. If by some device a Canadian court were able to invoke the defence as an excuse, it would engage the troubling proposition that the doctors were acting unlawfully, though understandably.

The restrictiveness of the Canadian law of necessity is also demonstrated in $R$. v. Latimer. In 1994 Robert Latimer was convicted of second degree murder for asphyxiating his daughter Tracey. ${ }^{52} \mathrm{~A}$ quadriplegic in continual and excruciating pain as a product of her cerebral palsy, she faced the prospect of further surgeries that would not alleviate and, indeed, might exacerbate the pain. In 1997, owing to the improper conduct of the prosecution with respect to the jury, the Supreme Court of Canada ordered a new trial. ${ }^{53}$ Latimer was again tried and convicted, but the jury recommended that he be eligible for parole after one year of custody. ${ }^{54}$ The judge sentenced Latimer to only one year of imprisonment, followed by one year of probation instead of the statutorily required life imprisonment with no parole eligibility for ten years. Latimer appealed the guilty verdict arguing, among other things, that the trial judge had erred in instructing the jury that the defence of necessity was not available.

The Saskatchewan Court of Appeal rejected this argument by holding that the defence was not available to Mr. Latimer. ${ }^{5 s}$ The Court upheld the trial judge's charge, in which Justice Noble, applying the reasoning in Perka, instructed the jury, inter alia, that necessity can only arise where there is imminent risk with no other choice available. Noble J. commented that "the decision to do it was taken some 12 days in advance of when he [the accused] actually did it. One must ask, as a result of that, how his situation could be described as an emergency." ${ }^{\text {"T6 }}$ The Court of Appeal found that "the defence of necessity was still left without the necessary 'air of reality' in relation to its essential elements, including the element of proportionality between the harm caused in violating the law and the harm entailed in abiding it." ${ }^{\text {" } 7}$ Furthermore, the Court agreed with the Attorney General's submission that the sentence was improper and substituted the life sentence. On appeal to the Supreme Court of Canada, a unanimous Court confirmed the Court of Appeal's conclusion that there was no air of reality to the defence of necessity. ${ }^{58}$

Ibid. at para. 355.

R. v. Latimer, [1994] S.J. No. 480 (Q.B.), online: QL (SJ).

R. v. Latimer (1997), 112 C.C.C. (3d) 193.

R. v. Latimer (1997), 121 C.C.C. (3d) 326.

R. v. Latimer (1998), 131 C.C.C. (3d) 191 [hereinafter Latimer].

Ibid. at 203-204.

Ibid. at 210 .

R. v. Latimer, [2000] I S.C.R. 3. 
This result is entirely consistent with and reaffirms the jurisprudence laid out in Perka. This case demonstrates, however, that the Canadian law of necessity has been so constricted that a jury will not be permitted to entertain a defence of necessity, either by way of justification or excuse, even in the face of such harrowing circumstances. The fact that the jury returned with the suggestion of a reduced punishment and that the trial judge saw fit to make an exception to the normal sentencing minimum shows that both judge and jury desperately wished to excuse the crime in some fashion. Canadian law, however, would not permit them to do so. The act was not sufficiently immediate, not sufficiently instinctual. He had not "acted 'involuntarily' in the sense of Perka." S99 Seemingly, Mr. Latimer's searching moral deliberations functioned in some way to disentitle him to the defence of necessity.

\section{Conclusion}

Unlike the German, French, and even the English criminal law, Canadian criminal law offers no means for the justice system to recognize that circumstances may arise in which breaking the letter of the law is the morally correct and, therefore, ultimately lawful thing to do. As for necessity-as-excuse, the defence has been so restricted by the Supreme Court of Canada that only in cases where the accused has responded to immediate emergencies with morally involuntary responses will the law permit a concession to onerous circumstance. Though entirely different on the facts, $A$ (Children) and Latimer are similar in that they involve extraordinarily difficult balances of values. While the former demonstrates an instance in which the English courts made use of concepts of necessity in exigent circumstances, the latter shows that Canada has to date effectively closed the door to these potentialities.

Many factors, not the least of which is technology, will likely contribute to test the law's ability to arbitrate among and balance between competing moral values. It seems the height of institutional hubris to claim that under no circumstances can breaking the law and thereby pursuing a higher value be justified. In order that the fundamental precepts of criminal liability be guarded, the law of defences must remain vital and flexible. The judicial and legislative curtailing of common law defences, particularly the defence of necessity, threatens to render the legal system morally irrelevant. If, like other jurisdictions, Canada recognized a justificatory defence based upon necessity, judges and juries would be able to remain faithful to the principle that only the morally blameworthy should be condemned. The legal system would be able to recognize those cases in which, owing to onerous circumstances and a powerful competing moral good, breaking the letter of the law would not be unlawful. In this area, morality and the law would be reintegrated. 